American Journal of Applied Sciences 6 (10): 1815-1819, 2009

ISSN 1546-9239

(C) 2009 Science Publications

\title{
A Review: Potentiality of Zooplankton as Bioindicator
}

\author{
${ }^{1}$ Zannatul Ferdous and ${ }^{2}$ A.K.M. Muktadir \\ ${ }^{1}$ Department of Zoology, University of Dhaka, Dhaka-1000, Bangladesh \\ ${ }^{2}$ Department of Surgery, Birmingham Heartlands Hospital, \\ 45 Bordesley Green E, Bordesley Green, Birmingham, B9, UK
}

\begin{abstract}
Problem statement: This review tended to summarize some recent research on zooplankton as bioindicator in India and some other countries of the world. Approach: These researches were mainly on fresh water bodies. Results: Qualitative as well as quantitative analysis were done by Shannon diversity index $\left(\mathrm{H}^{\prime}\right)$, Evenness index $(\mathrm{J})$, Species Richness index $(\mathrm{S})$ and Saprobic index. In most of the cases zooplankton population size was correlated with biotic and abiotic parameters $(\mathrm{pH}$, alkalinity, temperature, dissolve oxygen, transparency, phosphate, chlorine). Species of Rotifers, Cladocerans, Copepods and Ostracods were found in all cases. Species variation of these order deceased in polluted water. Some species were not found in some highly polluted area though these species have high tolerance level. Conclusion/Recommendations: All the results of the studies indicated that potentiality of zooplankton as bioindicator is very high. Other countries can develop these concepts to monitor water quality.
\end{abstract}

Key words: Zooplankton, bioindicator, biotic parameters, abiotic parameters

\section{INTRODUCTION}

Zooplankton are minute aquatic animals that are non motile or are very weak swimmers and they drift in water column of ocean, seas or fresh water bodies to move any great distance. Usually they move in the sunlit zone where food resources are most abundant and they also found in deep ocean water. They are heterotrophic in nature (sometimes detritivorous) and are the favorite food of a great many marine animals. Since zooplankton plays important role in food web by linking the primary producers (by consuming phytoplankton, mainly various bacterioplankton and sometimes zooplankton) and higher trophic levels. The freshwater zooplankton comprise of Protozoa, Rotifers, Cladocerans, Copepods and Ostracods.

- Planktonic protozoans are group of unicellular ciliated or flagellated organisms that feed on either picoplankton or nanoflagellates and small nanophytoplanktons according to their size. Most of the protozoans are usually not sampled due to their minute size. Heterotrophic nanoflagellates (about 1.0 to about $20 \mu \mathrm{m}$ in size) are more abundant $\left(10^{5}-10^{8} \mathrm{~L}^{-1}\right.$ in highly eutrophic lentic ecosystems) than ciliates $(8-300 \mu \mathrm{m}$ in size) in fresh water body. Only $10^{2}-10^{4} \mathrm{~L}^{-1}$ ciliates are found in fresh water ecosystem
- Rotifers are the most important soft-bodied metazoans (invertebrates) having a very short life cycle among the plankton. Only 100 widely spread rotifer species are planktonic and their life cycles are influenced by temperature, food and photoperiod. Dhanapathi ${ }^{[2]}$ found that they increase in large quantity rapidly under favorable environmental conditions

- Cladocerans are a crucial group among zooplankton and form the most useful and nutritive group of crustaceans for higher members of fishes in the food chain. This group feeds on smaller zooplankton, bacterioplankton and algae ${ }^{[4]}$ and are highly responsive against pollutants, this group even reacts against the low concentration of contaminants

- Among the all zooplankton, copepods have the toughest exoskeleton and the longest and the strongest appendages which help them to swim faster than any other zooplankton. Feeding habits differ in three orders of copepods. Cyclopoid copepods are commonly carnivorous (live on other zooplankton and fish larvae) though they also feed on algae, bacteria and detritus. The calanoid copepods are generally omnivorous (feed on ciliates, rotifers, algae, bacteria and detritus) however their food intake is dependent on their

Corresponding Author: Zannatul Ferdous, Department of Zoology, University of Dhaka, Dhaka-1000, Bangladesh Tel: 00-88-02-9015156/00-88-01819260081 
age, sex, season and food availability. The third group harpacticoid copepods are primarily benthic. Thus, their physical structures and versatile feeding habits ultimately assist them to hold up harsher environmental conditions as compared to cladocera $^{[3]}$

- Ostracods are mainly bottom dwellers of lakes and live on detritus and dead phytoplanktons. These organisms are food of fish and benthic macroinvertebrates $^{[6]}$

To monitor the aquatic ecosystems and integrity of water, plankton has been used recently as bio indicator ${ }^{[1,5]}$. Bioindicators and biotic indexes are being used by Europeans to assess water quality of water bodies ${ }^{[24]}$ for last 100 years. Potentiality of zooplankton as bioindicator is very high because their growth and distribution are dependent on some abiotic (e.g., temperature, salinity, stratification, pollutants) and biotic parameters (e.g., food limitation, predation, competition $)^{[7-9]}$. Another study ${ }^{[11]}$ in river Ramjan of Bihar, India revealed that abiotic parameters (e.g., pH, transparency, temperature, dissolved oxygen and some micronutrients) in relation to seasonal fluctuation influence zooplankton abundance. In this study, size of the Rotifer community was the largest one which showed a negative correlation with $\mathrm{pH}$, dissolved oxygen and transparency. Abundance of cladocera got second position among the total collection and showed negative correlation with $\mathrm{pH}$, transparency and phosphate. Copepoda, the third dense community, exhibited negative correlation with water temperature, nitrate and phosphate. Sahib ${ }^{[12]}$ observed the direct correlation between highly saturated dissolved oxygen level and zooplankton populations of Shendurni river, Kerela, India.

Community size of selected major zooplankton can indicate the trophic status of lakes and also can help to understand the shifts in trophic state. Many scientists worked with community sizes of Rotifera and Copepoda to show the different trophic states. The water quality of Fort lake Belgaum, Karnataka was determined by analyzing the community size of the zooplankton $^{[15]}$. Four groups of zooplankton (Rotifers, Cladocerans, Copepods and Ostracods) were recorded in this experiment where Rotifers were $52.38 \%$ of total zooplanktons, copepoda $26.5 \%$, Cladocerans $16.45 \%$ and Ostracods $4.67 \%$. High level of phosphate (7.2$13.6 \mathrm{mg} \mathrm{L}^{-1}$ ) leaded to eutrophication in the lake. This eutrophication successively influenced the growth of rotifers. Sampaio et al. ${ }^{[22]}$ studied relationship between trophic state of reservoir and diversity of zooplankton communities of 7 reservoirs of Paranapanema river,
Brazil. Diversity was evaluated using Shannon-Weiner index and Sorensen index. A positive relation had been found between trophic state of reservoir and diversity of zooplankton population. From 27 analyzed samples in 7 reservoirs, a total of 76 species of rotifers, 2 species of calanoid copepods, 5 species of cyclopoid copepod and 26 species of cladocerans were recorded. The values for the Shannon-Weiner index varied from 1.5-3.0 among the reservoirs. Whitman et al. ${ }^{[23]}$ determined the water quality of 11 northeastern Michigan coastal lakes using zooplankton assemblages. Strong correlations were observed between differences in lake trophic status and zooplankton community. The rotifers were found to be the best indicators of trophic status when compared to the other groups.

Maruthanayagam et $a l .{ }^{[10]}$ studied the season specific zooplankton diversity in Thirukkulam pond, Mayiladuthurai, Tamilnadu, India. This study showed that community size of zooplankton was the highest in rainy season while the lowest density of zooplankton was in summer due to the higher temperature. Among the all zooplankton copepods forming the dominant group followed by cladocera, rotifera and ostracoda. Five species of rotifera, four species of cladocera and three species each of ostracoda and copepoda were recorded. Sukumaran and Das ${ }^{[19]}$ studied plankton abundance in relation to physicochemical features of Mancharibele reservoir in Bangalore district of India. This study indicated that high chloride content and optimal temperature requirements for different groups of zooplankton favor their abundance in different seasons. Recorded groups of zooplankton were protozoa (largest population and represented by Arcella, Centrophyxis and Difflugia species), rotifera (second dominant group), cladocerans (six species were observed and less than rotifers community) and copepods (Diaptomus and Cyclops nauplii).

Jha and Barat ${ }^{[14]}$ carried out a qualitative analysis of zooplankton in lake Mirik in Darjeeling, Himalayas. This lake was polluted due to the pollutants let into the lake from external sources and the $\mathrm{pH}$ of the lake became acidic. It was confirmed by the analysis of other physiochemical parameters and planktons. In this condition, cladocerans (Moina, Daphnia, Bosmina) and copepods (Cyclops and Phyllodiaptomus were the most abundant among all copepods) were found. This research concluded that the lake cannot be used as a scarcity alternative for drinking water supply and these species serve as the bioindicator to determine the health of this aquatic body.

Fluctuation of abiotic factors i.e., concentration of dissolve oxygen, temperature, total alkalinity, total nitrogen, phosphate and $\mathrm{pH}$ can influence the growth of 
zooplankton $^{[16]}$. In this study, Rotiferas showed the most species variation among all other groups (copepods and cladocerans) while cladocerans were in the top according to abundance and Shannon index for zooplankton was found to vary in the fish culture pond. Das et al. ${ }^{[1]}$ established relationship between zooplankton community structure and physicochemical parameters (phytoplankton densities, $\mathrm{pH}$, alkalinity, nitrates and phosphates) by calculating Shannon diversity index $\left(\mathrm{H}^{\prime}\right)$, Evenness index $(\mathrm{J})$ and Species Richness index (S) and analyzing their interrelationship. It was found that $\mathrm{H}^{\prime}$ and $\mathrm{J}$ are closely related while no relationship with $\mathrm{S}$. Zooplankton densities were positively correlated with species Richness, phytoplankton densities, $\mathrm{pH}$ and alkalinity and negatively correlated with Evenness (J). Community of Copepods and Cladocerans were found where copepods were abundant. This abundance indicated the stable environmental conditions of Tasek lake. On the other hand Saha ${ }^{[20]}$ found that the evenness (J) showed insignificant relationship with species diversity index $\left(\mathrm{H}^{\prime}\right)$, species richness (S) showed negative relationship with species diversity index values in coal field areas of Jharkhand. He got 9 species each of cladocerans and rotifers, 7 species of copepoda and one species of ostracoda. He explained reason of negative relationship between species diversity index and species richness index as the effect of high alkalinity of water due to fly ash deposition.

Nutrient availability influences the predominance of rotifers and copepods ${ }^{[18]}$. The rotifers were represented by 5 species of Brachionus and 1 species of Tesdinella, indicating eutrophicated status. Copepods were mainly dominated by Mesocyclops species and cladocerans, the least abundant group comprise Moina species and Ceriodaphnia species. Ostracods showed photoperiodic on them (206 organisms $\mathrm{m}^{-1} 3$ at day and 555 organisms $\mathrm{m}^{-1} 3$ at night).

$\operatorname{Das}^{[19]}$ noticed significant negative correlation between net primary production and zooplankton production in a shrimp culture pond of Orissa. He also found that density of zooplankton population influenced by the season and copepods and rotifers were the dominant groups among all collected samples. In his research he showed that density of zooplankton was minimal in rainy and summer season.

According to Siddiqi and Chandrasekhar ${ }^{[21]}$, Trichotria tetratis could be used as the pollution indicator as they were found in the lake which was rich in phosphorus and other heavy metal ion. This species also found in past in sewage polluted tank. Not only phosphorous and metal ion but also high total alkanity, total hardness and high conductivity $\left(130 \mathrm{mS} \mathrm{m}^{-1}\right)$ of the water of that lake played as limiting factor for the growth of zooplankton.

The water quality at the Dubica Fish Pond of Serbia was monitored using zooplankton as bioindicator organisms during one production cycle of two year old carp in the year 2000. By qualitative and quantitative analysis of the zooplankton community, bioindicator species were selected for analyze water quality. The obtained results showed a general trend of decrease of saprobity index values from the beginning to end of the season. Gradual improvement of water quality is partly by natural process and partly an effect of proper application of icththyological, agrotechnical and hydrotechnical measures.

Structure of zooplankton assemblages was significantly influenced by different water quality of four man- made lakes in a tropical semi- arid region ${ }^{[24]}$. This response of zooplankton assemblages to water quality of these lakes, caused by eutrophication and siltation, was investigated by means of canonical correspondence analysis. Brachionus calyciflorus, Thermocyclops sp. and Argyrodiaptomus sp. were good indicators of eutrophic condition and B. dolabrotus, Keratella tropica and Hexarthra mira were good indicators of high turbidity due to suspended sediments.

\section{CONCLUSION}

In conclusion, these works were mainly on fresh water bodies. Qualitative as well as quantitative analysis were done by Shannon diversity index $\left(\mathrm{H}^{\prime}\right)$, Evenness index (J), Species Richness index (S) and Saprobic index. In most of the cases zooplankton population size was correlated with biotic and abiotic parameters $(\mathrm{pH}$, alkalinity, temperature, dissolve oxygen, transparency, phosphate, chlorine). Species of Rotifers, Cladocerans, Copepods and Ostracods were found in all cases. Species variation of these order deceased in polluted water. Some species were not found in some highly polluted area though these species have high tolerance level. All the results of the studies indicating that potentiality of zooplankton as bioindicator is very high. Other countries can develop these concepts to monitor water quality.

\section{REFERENCES}

1. Beaugrand, G., F. Ibanez and P.C. Reid, 2000. Spatial, seasonal and long-term fluctuations of plankton in relation to hydroclimatic features in the English channel, Celtic Sea and Bay of Biscay. Mar. Ecol. Prog. Ser., 200: 93-102. http://www.intres.com/articles/meps/200/m200p093.pdf 
2. Dhanapathi, M.V.S.S.S., 2000. Taxonomic notes on the rotifers from India (from 1889-2000). Indian Association of Aquatic Biologists (IAAB), Hyderabad.

http://wgbis.ces.iisc.ernet.in/energy/water/paper/Tr $-115 /$ ref.htm

3. J. Kalff, Limnology: Inland Water Ecosystems. 2nd Edn., Prentice Hall Publications, New Jersey, USA., pp: 592. http://wgbis.ces.iisc.ernet.in/energy/water/paper/Tr $-115 /$ ref.htm

4. Murugan, N., P. Murugavel and M.S. Kodarkar, 1998. Cladocera: The biology, classification, identification and ecology. Indian Association of Aquatic Biologists (IAAB), Hyderabad. http://wgbis.ces.iisc.ernet.in/energy/water/paper/Tr $-115 /$ ref.htm

5. Li, M., A. Gargett and K. Denman, 2000. What determines seasonal and interannual variability of phytoplankton and zooplankton in strongly estuarine systems? Application to the semienclosed estuary of Strait of Georgia and Juan de Fuca Strait. Estuarine Coastal Shelf Sci., 50: 467-488. http://www.cccma.ec.gc.ca/papers/kdenman/PDF/li garden00.pdf

6. Chakrapani, B.K., M.B. Krishna and T.S. Srinivasa, 1996. A Report on the water quality, plankton and bird populations of the lakes in and around Bangalore and Maddur, Karnataka, India. Department of Ecology and Environment, Government of Karnataka.

http://wgbis.ces.iisc.ernet.in/energy/water/paper/Tr $-115 /$ ref.htm

7. Beyst, B., D. Buysse, A. Dewicke and J. Mees, 2001. Surf zone hyperbenthos of Belgian sandy beaches: Seasonal patterns. Estuarine Coastal Shelf Sci., 53: 877-895. http://cat.inist.fr/?aModele $=$ afficheN\&cpsidt $=1344$ 1053

8. Christou, E.D., 1998. Interannual variability of copepods in a Mediterranean coastal area (Saronikos Gulf, Aegean Sea). J. Mar. Syst., 15: 523-532. DOI: 10.1016/S09247963(97)00080-8

9. Escribano, R. and P. Hidalgo, 2000. Spatial distribution of copepods in the North of the Humboldt Current region off Chile during coastal upwelling. J. Mar. Biol. Assoc. UK., 80: 283-290. http://wgbis.ces.iisc.ernet.in/energy/water/paper/Tr $-115 /$ ref.htm
10. Maruthanayagam, C., M. Sasikumar and C. Senthilkumar, 2003. Studies on zooplankton population in Thirukkulam pond during summer and rainy seasons. Nature Environ. Pollut. Technol., 2: 13-19.

http://wgbis.ces.iisc.ernet.in/energy/water/paper/Tr -115/TR115.pdf

11. Pandey, J. and A. Verma, 2004. The influence of catchment on chemical and biological characteristics of two freshwater tropical lakes of Southern Rajasthan. J. Environ. Biol., 25: 81-87. http://wgbis.ces.iisc.ernet.in/energy/water/paper/Tr $-115 /$ ref.htm

12. Sahib, S.S., 2004. Physico-chemical parameters and zooplankton of the Shendurni River, Kerala. J. Ecobiol., 16: 159-160. http://www.monoculus.org/M48Supplement.pdf

13. Sukumaran, P.K. and A.K. Das, 2002. Plankton abundance in relation to physicochemical features in a peninsular man-made lake. Environ. Ecol., 20: 873-879.

http://wgbis.ces.iisc.ernet.in/energy/water/paper/Tr $-115 /$ ref.htm

14. Jha, P. and S. Barat, 2003. Hydrobiological study of lake Mirik in Darjeeling, Himalayas. J. Environ. Biol., 24: 339-344.

http://www.springerlink.com/content/d5r628876u3 62046/

15. Sunkad, B.N. and H.S. Patil, 2004. Water quality assessment of fort lake of Belgaum (Karnataka) with special reference to zooplankton. J. Environ. Biol., 25: 99-102. www.envisiitr.org.in/newsletter/envis-news-letter-2009-02.pdf

16. Sarkar, S.K. and B. Chowdhury, 1999. Limnological Research in India. 1st Edn., Daya Publishing House, ISBN: 0-08-0967579-5, pp: 108-130.

17. Das, P.K., R.G. Micheal and A. Gupta, 1996. Zooplankton community structure of lake Tasek, a tectonic lake in Garo hills, India. Trop. Ecol., 37: 257-263.

http://cat.inist.fr/?aModele $=$ afficheN\&cpsidt $=10145855$

18. A. S.Kumar, Tripathi and P. Ghosh, 2004. Status of Freshwater in 21 Century: A Review. In: Water Pollution: Assessment and Management, Kumar, A. and G. Tripathi (Eds.). Daya Publishers, Delhi, ISBN: 0-09-01265409-3, pp: 520.

http://wgbis.ces.iisc.ernet.in/energy/water/paper/Tr $-115 /$ index.htm

19. Das, S.K., 2002. Primary production and zooplankton biodiversity in brackish water shrimp culture pond. J. Ecobiol., 14: 267-271. http://wgbis.ces.iisc.ernet.in/energy/water/paper/Tr $-115 /$ index.htm 
20. Saha, T.K., 2004. Net plankton diversity in coal mining areas of Jharkhand. Ecol. Environ. Conserv., 10: 11-16.

http://direct.bl.uk/bld/PlaceOrder.do?UIN=151941 $760 \&$ ETOC $=$ RN\& from $=$ searchengine

21 Siddiqui, S.Z. and S.V.A. Chandrasekhar, 1996. New distribution record of Trichotria tetractis (Rotatoria/Trichotridae) and Daphnia lumholtzi (Brachiopoda/Cladocera/ Daphnidae) from Kolleru lake andhra Pradesh with notes on indicator value. J. Bombay Natural History Soc., 93: 309-310. http://wgbis.ces.iisc.ernet.in/energy/water/paper/Tr $-115 /$ index.htm

22. Sampaio, E.V., O. Rocha, T. Matsumura-Tundisi and J.G. Tundisi, 2002. Composition and abundance of Zooplankton in the limnetic zone of seven reservoirs of the Paranapanema River, Brazil. Braz. J. Biol., 62: 525-545. DOI: 10.1590/S1519-69842002000300018
23. Whitman, R., B.M. Nevers, L.M. Goodrich, C.P. Murphy and M.B. Davis, 2004. Characterization of lake Michigan coastal lakes using zooplankton assemblages. Ecol. Indicat., 4: 277-286. DOI: 10.1016/J.ECOLIND.2004.08.001

24. Sousa, W., J. Attayde, E. Rocha and E. Eskwazi- Santanna, 2008. The response of zooplankton assemblages to variations in the water quality of four man-made lakes in semi-arid northeastern Brazil. J. Plankton Res., 30: 699-708. DOI: $10.1093 /$ plankt/fbn032 